\title{
Microglioma with paraproteinaemia
}

\author{
C. D. LAMBERT AND P. N. TREWBY \\ From the Department of Neurology, St George's Hospital, London
}

SYNOPSIS A case is reported in which a solitary intracerebral tumour of lymphoreticular cells (microglioma, reticulum cell sarcoma) was associated with the presence of a serum paraprotein. Extensive investigation failed to show any evidence of extracerebral reticulosis. Response of the paraprotein to treatment of the tumour is described.

The term microglioma, or reticulum cell sarcoma, is applied to a tumour arising from those cells representing the reticuloendothelial system in the central nervous system. The clinical features of this uncommon tumour together with discussions of nomenclature and definition have been reported in several papers (Adams and Jackson, 1963; Burnstein et al., 1963; Miller and Ramsden, 1963; Rubenstein, 1964; Schaumburg et al., 1972). Little attention, however, has been paid to biochemical abnormalities in this condition. This paper describes the occurrence of a monoclonal macroglobulin band in the serum of a patient with an intracerebral microglioma in whom extensive tests showed no extracerebral neoplastic focus. The effect of treatment on this paraprotein was of particular interest.

\section{CASE HISTORY}

In July 1972 a 71 year old man presented with a three week history of difficulty in avoiding objects on the right side. He also noticed headaches, hesitancy of verbal expression, and difficulty in reading, and he made mistakes with simple daily tasks. Rapid deterioration over two weeks led to hospital admission.

Examination showed him to be fully alert and cooperative, but with a marked dysphasia. He had a dressing apraxia, and could not orientate himself to rise from his bed or to sit in a chair. A right homonymous hemianopia was present, and also mild weakness of the right arm, with pseudo-athetoid movements of this arm and right-sided sensory inattention. Both plantar responses were extensor. General examination disclosed no abnormality and, in par- ticular, the fundi were normal, the pulse regular, and the blood pressure was $140 / 70 \mathrm{mmHg}$. No cardiac or neck bruits were heard and there was no hepatosplenomegaly or lymphadenopathy.

Radiographs of the skull and chest were normal. A brain scan showed a large area of increased uptake of isotope in the left occipital lobe and carotid

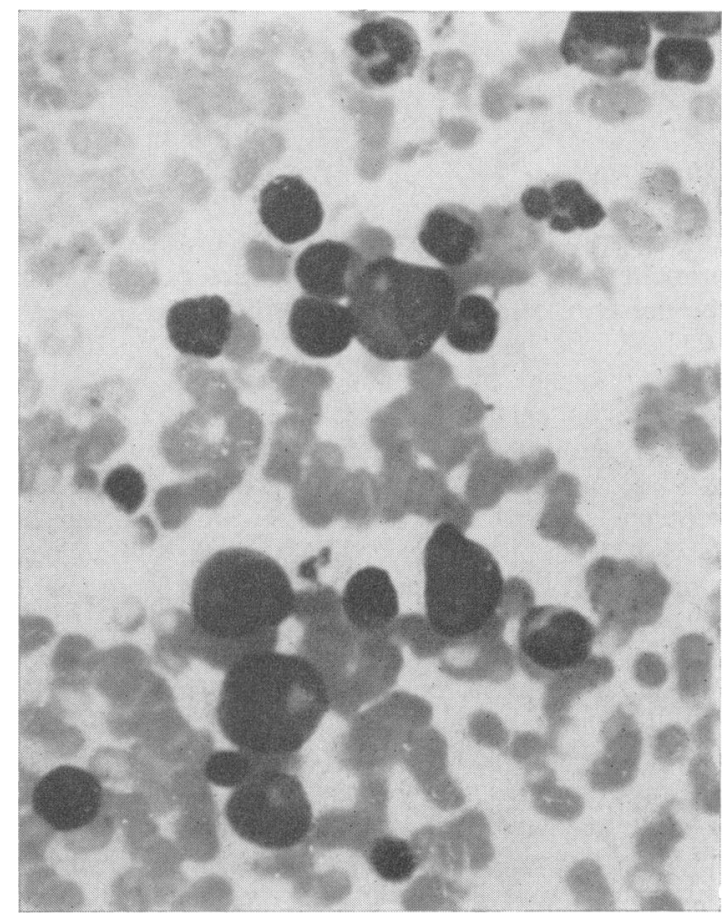

FIG. 1. Bone marrow aspirate May-GrunwaldGiemser stain, $\times 600$. 


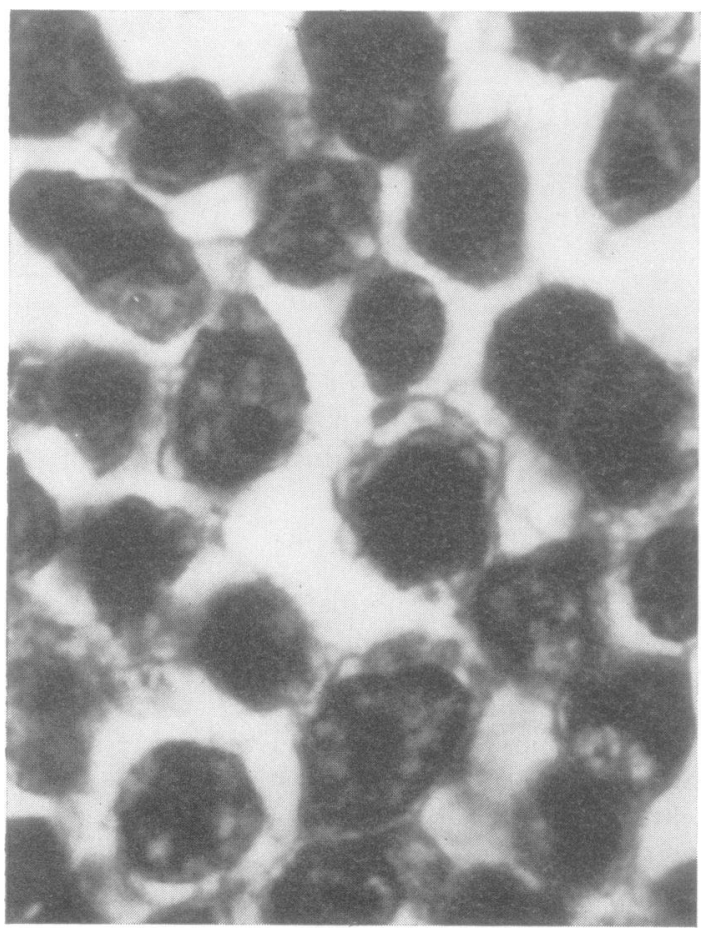

FIG. 2. Large primitive lymphoreticular cells with prominent nucleoli, coarse nuclear chromatin and a small rim of cytoplasm. $H$ and $E, \times 1,700$.

angiography demonstrated elevation of the posterior branches of the left middle cerebral artery, suggesting the presence of an avascular occipital mass.

The blood haemoglobin level was $13.7 \mathrm{~g} / 100 \mathrm{ml}$ with a normal blood film and normal white cell count. The erythrocyte sedimentation rate (ESR, Westergren) on three occasions was markedly raised at 53,59, and $93 \mathrm{~mm}$ per hour. Analysis of the serum proteins showed a normal total concentration of $7 \cdot 1 \mathrm{~g} / 100 \mathrm{ml}$ but on electrophoresis a well-defined monoclonal band was present in the gamma 1 region. No Bence-Jones proteinuria was detected.

Sternal marrow aspiration showed normal erythropoiesis and granulopoiesis with megakaryocytes present in normal numbers. The myeloid-erythroid ratio was normal. Plasma cells were present in normal numbers. There was some variability of morphology, suggesting reactivity, but no obvious malignant characteristics were apparent. No malignant cells were seen. Staining with iron showed normal amounts to be present (Fig. 1). A repeat aspiration six weeks later, from the iliac crest, showed no evidence of infiltration, and haemopoiesis

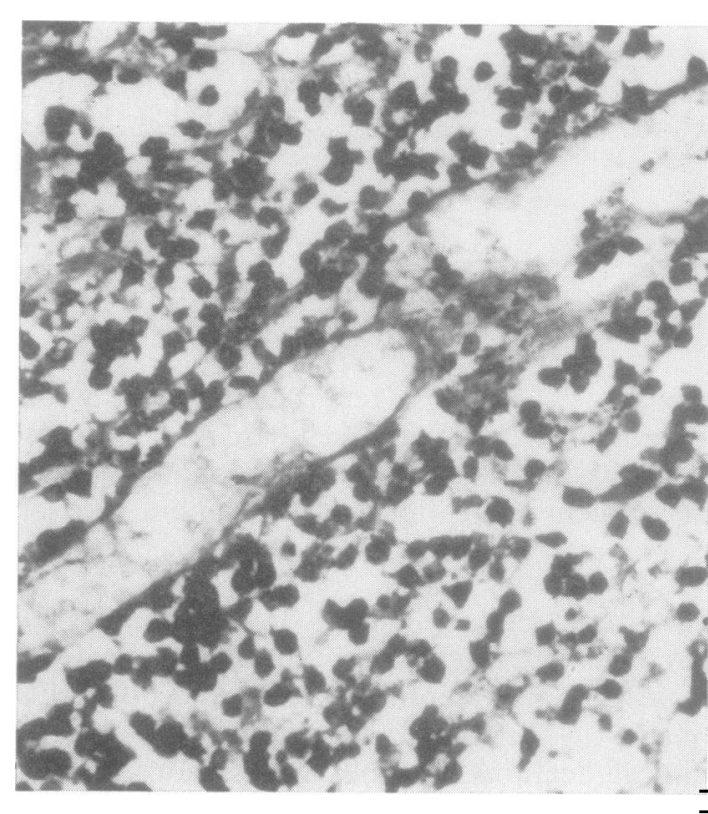
FIG. 3. Silver impregnation of tumour cells demorid
strating metallophilia, $\times 192$.

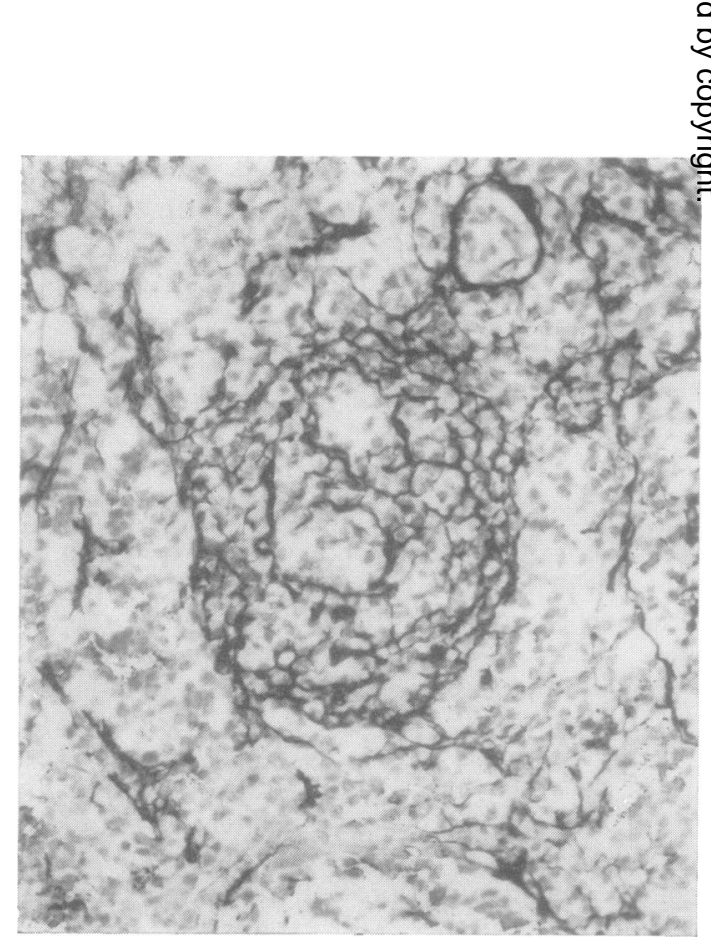

FIG. 4. The characteristic perivascular reticulin appearances. Gordon and Sweet's stain, $\times 160$. 
was normal. A radiological skeletal survey, lymphangiogram, intravenous pyelogram, and liver and spleen isotopic scan showed no evidence of extracerebral neoplasia. Other investigations performed were: plasma urea $33 \mathrm{mg} / 100 \mathrm{ml}$, sodium 137 $\mathrm{mEq} / \mathrm{l}$, potassium $4.9 \mathrm{mEq} / 1$, bicarbonate $25 \mathrm{mEq} / 1$, calcium 9.0 and $8.8 \mathrm{mg} / 100 \mathrm{ml}$, phosphate 3.3 and 3.2 $\mathrm{mg} / 100 \mathrm{ml}$, alkaline phosphatase 8 and $7 \mathrm{King}$ Armstrong units, uric acid $4.5 \mathrm{mg} / 100 \mathrm{ml}$, bilirubin $0.5 \mathrm{mg} / 100 \mathrm{ml}$, cholesterol $196 \mathrm{mg} / 100 \mathrm{ml}$, and random blood sugar levels 106 and $121 \mathrm{mg} / 100 \mathrm{ml}$. Blood Wassermann reaction and Reiter protein test were negative; the cerebrospinal fluid contained protein, $51 \mathrm{mg} / 100 \mathrm{ml}$, sugar $51 \mathrm{mg} / 100 \mathrm{ml}$, and six normal lymphocytes per $\mathrm{mm}^{3}$.

Five weeks after the onset of symptoms the patient was started on dexamethasone $4 \mathrm{mg}$ four times daily with considerable improvement after 24 hours, particularly in speech and writing. Repeat protein electrophoresis three days after starting steroid treatment was normal.

Six weeks after the onset of symptoms craniotomy was performed ( $\mathrm{Mr}$ A. E. Richardson). A firm rubbery tumour was encountered $3 \mathrm{~cm}$ below the occipital cortex. It was variable in colour from yellowish to grey-blue with necrotic elements and firm areas. Above, it blended with the ventricular ependyma and below reached the brain surface and was adherent to the tentorium. The main tumour bulk was intracerebral. A subtotal removal was performed.

Microscopical examination revealed a highly cellular, partly necrotic malignant tumour. The majority of the cells were characterized by large nuclei, containing multiple nucleoli, and relatively sparse cytoplasm. Mitotic figures were frequent. Mature microglia, lymphocytes, and plasma cells were also present. Reticulin impregnations showed the characteristic perivascular pattern of lamellar splitting and fragmentation of the adventitial reticulin of the affected vessels. With silver staining methods for microglia many cells showed metallophilia. The histological features were those of a microglioma (Dr R. Crompton) (Figs 2, 3, and 4).

The postoperative course was uneventful. Twenty days after surgery repeat protein electrophoresis showed no evidence of the previous monoclonal band and quantitative protein analysis showed only simple hypoproteinaemia. The patient was maintained on dexamethasone and three weeks after operation was transferred to the Royal Marsden Hospital (under the care of Dr Bloom) for radiotherapy.

Four weeks postoperatively, repeat protein electrophoresis demonstrated return of the mono- clonal band in the mid gamma region, and this was shown to be an IgM paraprotein of $\mathrm{K}$ light chain type with a concentration of $660 \mathrm{mg} / 100 \mathrm{ml}$ (n.v. $60-250 \mathrm{mg} / 100 \mathrm{ml}$ ). The serum IgG and IgA levels were depressed, their concentrations being $440 \mathrm{mg} /$ $100 \mathrm{ml}$ (n.v. $800-1,800 \mathrm{mg} / 100 \mathrm{ml}$ ) and $24 \mathrm{mg} / 100 \mathrm{ml}$ (n.v. $90-450 \mathrm{mg} / 100 \mathrm{ml}$ ) respectively. The patient was maintained on $1 \mathrm{mg}$ dexamethasone four times daily; eight days later the $\operatorname{IgM}$ concentration had risen to $1,500 \mathrm{mg} / 100 \mathrm{ml}$.

The patient underwent a six weeks' course of radiotherapy; a dose of 5,000 $r$ was given to the site of the occipital lobe tumour with a prophylactic 3,000 $r$ to the remainder of the brain and spinal cord. At the end of this treatment the serum IgM level was still raised at $640 \mathrm{mg} / 100 \mathrm{ml}$ but the $\mathrm{IgG}$ concentration was now normal at $1,045 \mathrm{mg} / 100 \mathrm{ml}$. The IgA level remained depressed at a concentration of $31 \mathrm{mg} /$ $100 \mathrm{ml}$.

When seen again in the Neurological Department two months after completion of radiotherapy, the patient was well and the only residual neurological signs were a mild dysphasia, a complete right homonymous hemianopia, and bilateral extensor plantar responses. The haemoblobin level was 11.6 $\mathrm{g} / 100 \mathrm{ml}$ and the ESR $20 \mathrm{~mm}$ in one hour. Repeat protein electrophoresis now showed only simple hypoproteinaemia. No paraprotein was present. One year after presentation the neurological signs were similar. Asymptomatic complete heart block was now present. A weight loss of $4.5 \mathrm{~kg}$ had occurred but no evidence of extracerebral malignancy was apparent on examination. The haemoglobin was $12 \mathrm{~g} / 100 \mathrm{ml}$, with an ESR of $35 \mathrm{~mm}$ in one hour (Westergren). No paraprotein band was present on serum electrophoresis. Liver and spleen scans were normal.

\section{DISCUSSION}

While in the past confusion has existed regarding the terminology and classification of tumours of the microglioma type, it is now agreed that microglial cells are the chief representatives of the lymphoreticular system normally present in cerebral tissues. The mature microglia are metallophilic - that is, they can be impregnated with silver salts-and in response to suitable stimuli act as macrophages. They evolve from primitive non-metallophil precursor cells found in the meninges and Virchow-Robin spaces, and in any microglioma varying proportions of metallophil microglial and non-metallophil pre- 
cursor cells may be present. In addition, plasma cells, giant cells, and lymphocytes may be present in varying proportions (Marshall, 1956; Russell, 1948). In an electron microscopic study of reticulum cell sarcoma (microglioma), Horvat et al. (1969) showed the ultrastructure of the cerebral tumour to be similar to extracerebral reticulum cell sarcoma and to experimentally induced microgliosis.

The relationship between microgliomata and tumours of the reticuloendothelial system has led several authors to suggest that abnormalities of the serum proteins might occur in the serum of patients with microgliomata (Adams and Jackson, 1966; Dutcher and Fahey, 1959). In the majority of reports, however, few biochemical details are given and the serum proteins are rarely commented upon. When paraproteinaemia has been demonstrated, extensive extracerebral involvement has usually been present.

The relationship between hyperglobulinaemia and neurological symptoms was first described by Bing and Neel in 1936, and the association of neurological symptoms with macroglobulinaemia has since been designated the Bing-Neel syndrome. In Waldenström's macroglobulinaemia, systemic manifestations predominate with lymphocytic-plasmacytoid proliferation in lymph nodes, liver, and spleen but neurological manifestations occur in about one-quarter of patients with this disease (Logothesis et al., 1960). Reviewing 182 cases, these authors classified the neurological manifestations into acute focalon lesions, encephalopathies, neuropathies, sub- قَق arachnoid haemorrhage, and mixed forms. In the encephalopathic group 10 necropsy reports were available and lymphoid and plasma cell infiltrations were found in the brain and meninges in all cases.

Edgar and Dutcher (1961) reported one $\stackrel{\bar{F}}{+}$ patient with two discrete cerebral microgliomata. The ESR was raised to $89 \mathrm{~mm}$ in one hour and $\frac{\bar{c}}{\bar{s}}$ ultracentrifugation of the serum showed a raised $\vec{\nabla}$ macroglobulin concentration comprising $15 \%$ of

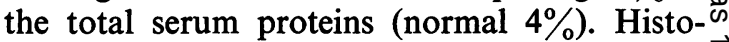
logical examination revealed the presence of $\vec{\circ}$ metallophilic microglioma cells and non- $\overrightarrow{\vec{\omega}}$ metallophilic reticulum cells together with a diffuse perivascular infiltration of lymphocytes $\overline{3}$ and plasma cells. The patient also had hepato-? splenomegaly and at postmortem examination. the liver, spleen, lymph nodes, kidneys, and spinal cord were shown to be affected by similis cellular infiltrates.

응

Horvat et al. (1969) reported a patient with primary reticulum cell sarcoma (microgliom@) $气$ of the brain and commented upon the presene of a sharp peak in the beta globulin fraction 0 the serum proteins. No other biochemical detaifs. were given. No reference was made to extra-

TABLE

SUMMARY OF PARAPROTEIN ABNORMALITIES DURING TREATMENT

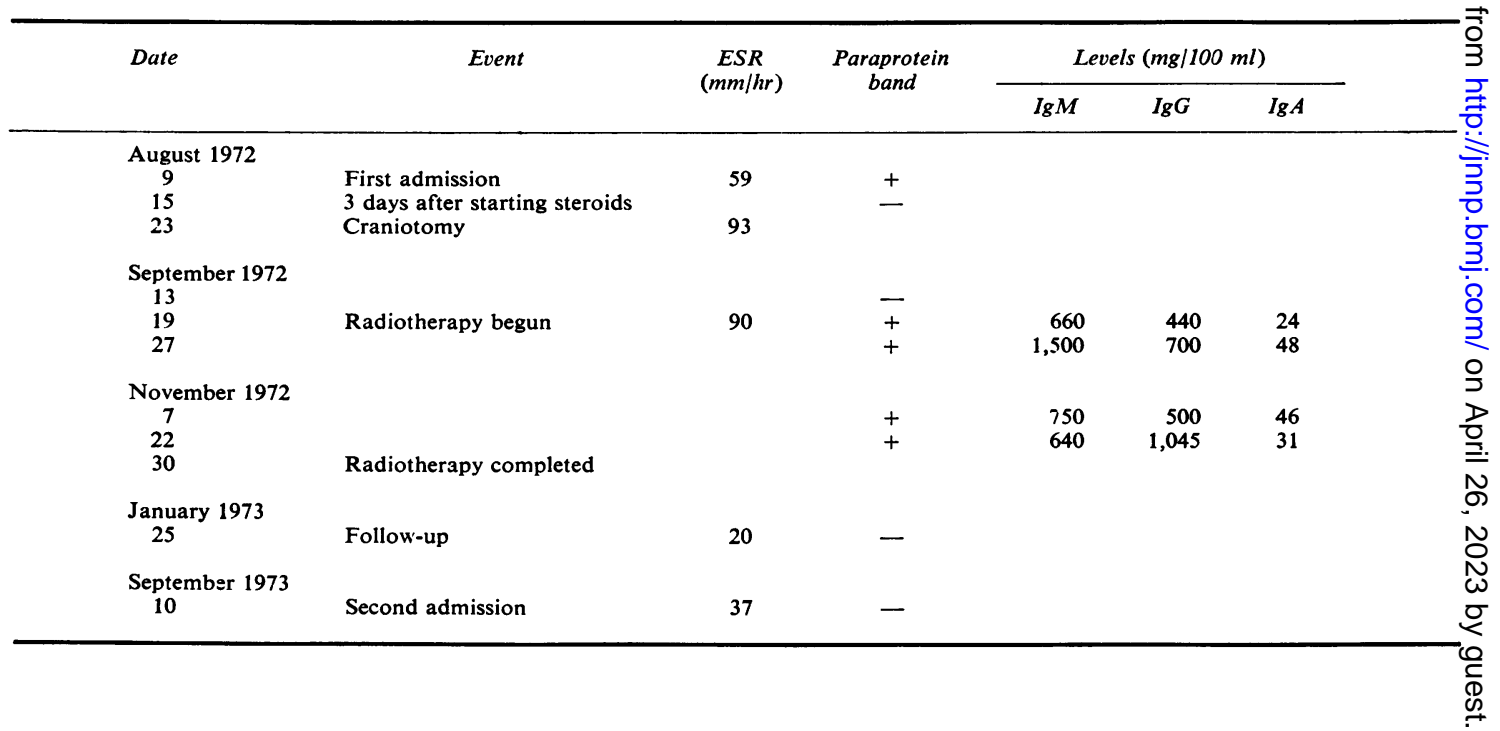


cerebral involvement. The tumour was removed at craniotomy and the authors noted that the predominant cell type in this cerebral tumour was indistinguishable from that noted in the lymph nodes of three other patients with extracerebral reticulum cell sarcoma, except for the absence of intranuclear inclusions and cytoplasmic crystalloids in the extracerebral tumour cells. Both these were present in the cerebral tumour and the authors comment on the association between cytoplasmic crystalloids and cellular secretory products.

Gunderson et al. (1971) reported five cases of microglioma in which serum electrophoresis was performed. No mention was made of paraprotein bands. In one case, immunoelectrophoresis and bone marrow aspiration produced the typical findings of Waldenström's macroglobulinaemia with an elevated serum IgM concentration. Necropsy revealed a poorly defined occipital microglioma, with extensive infiltration of the bone marrow, spleen, and lymph nodes with lymphoblasts, lymphocytes, and plasma cells. In the four other cases, serum electrophoresis was normal, although one case showed a slight elevation of the gamma-1 and gamma-2 globulins; the serum albumin and total serum protein in this patient were reduced. In two of these patients in whom serum electrophoresis was normal, immunodiffusion studies were performed. One patient showed a raised IgA level of $780 \mathrm{mg} / 100 \mathrm{ml}$ (n.v. $61-330 \mathrm{mg} / 100 \mathrm{ml}$ ). It is not evident at which stage this determination was made, nor is there any comment concerning possible extracerebral involvement.

In our patient, serum electrophoresis before treatment revealed a monoclonal band in the mid gamma region and immunoelectrophoresis showed the band to consist of macroglobulins with a maximum recorded serum level of 1,500 $\mathrm{mg} / 100 \mathrm{ml}$. No immunoglobulin estimation was performed on cerebrospinal fluid (CSF) although a raised CSF protein is a common finding in microgliomata, so that immunoglobulin abnormalities might be expected. The effect of treatment on this monoclonal band was of particular interest (Table). Three days after starting steroid therapy no monoclonal band was detected and protein electrophoresis remained normal when repeated three weeks postoperatively. However, one week later the monoclonal band had returned and immunoglobulin analysis showed it to consist of an IgM with a concentration of $660 \mathrm{mg} / 100 \mathrm{ml}$. Suppression of $\mathrm{IgG}$ and IgA was noted and this was suggestive of a malignant reticulosis. The patient was maintained on a small dose of steroids but eight days later the concentration of IgM had risen to 1,500 $\mathrm{mg} / 100 \mathrm{ml}$. After six weeks' radiotherapy the concentration had fallen to $640 \mathrm{mg} / 100 \mathrm{ml}$ and the IgG concentration was within normal limits. Ten weeks after the radiotherapy course was completed the monoclonal band was absent, and remained so one year later.

Although a number of non-malignant diseases may be associated with paraproteinaemia (Cooke, 1969), our patient showed no evidence of any such disorder. It would seem highly probable that the microglioma was associated with the production of the paraprotein. In a small number of patients transient paraproteinaemia has been recorded (Young, 1969) and in one such case where spontaneous disappearance of the paraprotein occurred, neurological symptoms were present (Nutter and Kramer, 1965). In the present case, however, the close correlation between treatment and the presence or absence of the monoclonal band suggests that the treatment given was responsible for suppression of paraprotein production. Steroids and surgery produced temporary suppression, while radiotherapy produced a more prolonged effect.

The importance of radiotherapy may relate to the frequently recorded observation that cerebral involvement by microglioma is more extensive than macroscopic examination would suggest. Extensive microscopic spread may be present, or multiple tumour foci at remote areas may occur (Fisher et al., 1959; Burstein et al., 1963; Miller and Ramsden, 1963). In several reports there has been no macroscopic evidence of tumour involvement, yet microscopically diffuse cellular infiltration has been noted at postmortem examination (Adams and Jackson, 1962; Kakulas and Finlay-Jones, 1962).

The present case demonstrates the rapidly progressive course commonly found in these tumours, and the good response to surgery if combined with radiotherapy (Burstein et al., 1963; Schaumberg et al., 1972). It also demonstrates a relationship between paraproteinaemia and an apparently solely intracerebral tumour of 
reticuloendothelial origin, a situation which has not been clearly documented previously. Awareness of this may facilitate the preoperative diagnosis of microglial tumours of the brain, and in future cases enable a more detailed study of the distribution of paraproteins between the CSF and blood to be undertaken. It might also be possible to demonstrate paraprotein production in tissue culture of microgliomata removed at surgery. The occurrence of microgliomata in situations in which immune competence is disturbed-for example, in the Wiskott-Aldrich syndrome (Brand and Markinovitch, 1969) or after renal transplantation (Schneck and Penn, 1970)-suggests that, although uncommon, these tumours may be seen with increasing frequency and, in a recent survey of renal transplant recipients (Hoover and Fraumeni, 1973), the risk of reticulum cell sarcoma was found to be 350 times greater than expected.

We are most grateful to Dr P. C. Gautier-Smith, Dr H. J. G. Bloom, and Mr A. E. Richardson for allowing us to report on a patient under their care, and to Dr R. Crompton for providing the histology and to Dr G. Franglen for his most helpful comments concerning protein analysis. We are especially indebted to Dr R. O. Barnard for his expert advice and encouragement and for providing the photomicrographs.

\section{REFERENCES}

Adams, J. H., and Jackson, J. M. (1966). Intracerebral tumours of reticular tissue: the problem of microgliomatosis and reticulo-endothelial sarcomas of the brain. Journal of Pathology and Bacteriology, 91, 369-381.

Bing, J., and Neel, A. V. (1936). Two cases of hyperglobulinaemia with affection of the central nervous system on a toxi-infectious basis. Acta Medica Scandinavica, 88, 492506.
Brand, M. M., and Marinkovitch, V. A. (1969). Primary malignant reticulosis of the brain in Wiskott-Aldrich syn-D drome. Report of a case. Archives of Diseases in Childhood, 44, 536-542.

Burstein, S. D., Kernohan, J. W., and Uihlein, A. (1963). Neoplasms of the reticuloendothelial system of the brain. Cancer, 16, 289-305.

Cooke, K. B. (1969). Essential paraproteinaemia. Proceeding $5<$ of the Royal Society of Medicine, 62, 777-778.

Dutcher, T. F., and Fahey, J. L. (1959). The histopathology of the macroglobulinemia of Waldenström. Journal of the National Cancer Institute, 22, 887-917.

Edgar, R., and Dutcher, T. F. (1961). Histopathology of the Bing-Neel syndrome. Neurology (Minneap.), 11, 239-245.

Fisher, E. R., Davis, E. R., and Lemmen, L. J. (1959). Reticulum-cell sarcoma of brain (microglioma). Archives $\overline{\bar{c}}$ of Neurology and Psychiatry, 81, 591-598.

Gunderson, C. H., Henry, J., and Malamud, N. (1971). Plasma globulin determination in patients with microglioma. Journal of Neurosurgery, 35, 406-415.

Hoover, R., and Fraumeni, J. F., Jr (1973). Risk of cancer in $\vec{\circ}$ renal-transplant recipients. Lancet, 2, 55-57.

Horvat, B., Pena, C., and Fisher, E. R. (1969). Primaryc reticulum cell sarcoma (microglioma) of brain. An electrong microscopic study. Archives of Pathology, 87, 609-616.

Kakulas, B. A., and Finlay-Jones, L. R. (1962). A lymphomaO with central nervous system involvement. Case report. $\omega$ Neurology (Minneap.), 12, 495-500.

Logothetis, J., Silverstein, P., and Coe, J. (1960). Neurologicaspects of Waldenström's macroglobulinemia. Archives Neurology, 3, 564-573.

Marshall, A. H. E. (1956). An Outline of the Cytology $\stackrel{\mathbb{D}}{\mathrm{D}} \frac{\mathrm{O}}{\mathrm{a}}$ Pathology of the Reticular Tissue. Oliver and Boye:Edinburgh.

Miller, A. A., and Ramsden, F. (1963). Primary reticulosis@ి the central nervous system 'microgliomatosis'. $A$ a Neurochirurgica, 11, 439-478.

Nutter, D. O., and Kramer, N. C. (1965). Macrocryogetglobulinemia. Report of a case, with unusual spontaneous recovery. American Journal of Medicine, 38, 462-469.

Rubinstein, L. J. (1964). Microgliomatosis. Acta Neurochirurgica, Suppl. 10, 201-217.

Russell, D. S., Marshall, A. H. E., and Smith, F. B. (1948). Microgliomatosis. Brain, 71, 1-15.

Schaumburg, H. H., Plank, C. R., and Adams, R. D. (1972). The reticulum cell sarcoma-microglioma group of brain tumours. Brain, 95, 199-212.

Schneck, S. A., and Penn, I. (1970). Cerebral neoplasmsassociated with renal transplantation. Archives of Neurology, 22, 226-233.

Young, V. H. (1969). Transient paraproteins. Proceedings of the Royal Society of Medicine, 62, 778-780. 